\title{
Pembuatan Komposit sebagai Bahan Peredam Bunyi
}

\author{
Indah Safitri ${ }^{1^{*}}$, Parmin Lumbantoruan ${ }^{1}$, Andi Arif Setiawan ${ }^{1}$ \\ ${ }^{1}$ Program Studi Fisika Fisika, Sains dan Teknologi Universitas PGRI Palembang, \\ Palembang 30251, Indonesia \\ *e-mail:indahsyafitri9696@gmail.com
}

Received: 07 Januari 2021. Accepted: 30 Januari 2021. Published: Februari 2021

\begin{abstract}
Abstrak
Kebisingan merupakan salah satu bentuk dari polusi, berdampak pada manusia. Kebisingan itu dapat diminimalisir dengan pembuatan peredam bunyi. Tujuan Penelitian ini mengkaji seberapa besar tingkat bunyi yang dapat ditahan oleh komposit campuran ijuk dan gipsum. Metode berupa pengukuran mengukur intensitas bunyi dari sumber bunyi, dimana sumber bunyi tersebut diletakkan dalam kotak yang ditutupi oleh bahan komposit dan dibandingkan sumber bunyi tanpa penutup komposit. Bahan komposit tersebut terdiri komposit 1 (10gram Ijuk, 35 gram Gipsum, 50 gram Semen putih), komposit 2 (15 gram Ijuk, 30 gram Gipsum, 50 gram Semen putih), Komposit 3 (20 gram Ijuk, 25 gram Gipsum, 50 gram Semen putih), Komposit 4 (30 gram Ijuk, 15 gram Gipsum, 50 gram Semen putih), Komposit 5 (35 gram Ijuk, 10 gram Gipsum, 50 gram Semen putih). Intensitas bunyi dengan menggunakan Komposit I yaitu dengan nilai $(67,9)$, Komposit II yaitu dengan nilai $(66,6) \mathrm{dB}$, Komposit III yaitu dengan nilai $(77,6) \mathrm{dB}$, Komposit IV yaitu dengan nilai $(68) \mathrm{dB}$, dan Komposit V yaitu dengan nilai (72) $\mathrm{dB}$.
\end{abstract}

Kata kunci: Kebisingan, Tingkat Intensitas Bunyi, Ijuk dan Gipsum.

\section{Manufacture of Composites as Sound-Dampening Materials}

\begin{abstract}
Noise is a form of pollution, it has an impact on humans. Noise can be minimized by making silencers.The purpose of this study was to examine how much sound level can be retained by the composite of a mixture of fibers and gypsum. The method is a measurement of measuring the intensity of the sound source, where the sound source is placed in a box covered by composite material and compared to sound source without a composite. Composite materials consist of a composite of one (10 grams of palm fiber, 35 grams of gypsum and 50 grams of white cement), composite 2 (15 grams palm fiber,30 grams of gypsum, and 50 grams of white cement), composite 3 (20 grams of palm fiber, 25 grams of gypsum and 50 grams of white cement), composite 4 (30 grams of palm fiber, 15 grams gypsum, and 50 grams white cement), and composite 5 (35 grams of palm fiber, 10 grams of gypsum and 50 grams of white cement). Sound intensity by using composite 1, namely the value of $(67,9) \mathrm{dB}$,composite 2 that is with the value of $(66,6) d B$, composite 3 that is with the value of $(77,6) d B$, composite 4 that is with the value of (68) $d B$, composite 5 that is with the value of (72) $d B$,
\end{abstract}

Keywords: noise, sound intensity level, fibers and gypsum.

\section{PENDAHULUAN}

Bunyi merupakan gelombang mekanik longitudinal yang merambat dan sumbernya berupa benda yang bergetar. Bunyi yang dapat didengar manusia berada pada kawasan frekuensi 
pendengaran, yaitu antara $20 \mathrm{~Hz}$ sampai dengan $20 \mathrm{kHz}$ (Yasid et.al., 2016). Kebisingan adalah salah satu bentuk dari polusi yang dapat menimbulkan tekanan lingkungan dan akan berdampak secara fisik maupun non fisik kepada manusia.

Sumber kebisingan yaitu adanya suara-suara yang dihasilkan oleh alat-alat proses produksi yang memiliki intensitas bunyi melebihi ambang batas. Cara mengatasi dampak kebisingan yaitu dengan cara membuat suatu material peredam bunyi untuk melindungi telinga yaitu komposit matriks polimer yang mampu meredam bunyi sehingga kebisingan dapat berkurang. Energi bunyi mampu diserap oleh material yang bersifat berpori, berserat dan lebih mudah didapatkan (Pawestri et al., 2018,113)

Sumber kebisingan yaitu adanya suara-suara yang dihasilkan oleh alat-alat proses produksi yang memiliki intensitas bunyi melebihi ambang batas, oleh karena itu diperlukan bahan peredam.

Kebutuhan akan bahan peredam bunyi pada saat sekarang ini mengalami peningkatan yang sangat tinggi sehingga perlu dicari alternatif bahan atau komposit yang dapat meredam bunyi.

Energi bunyi mampu diserap oleh material yang bersifat berpori, berserat dan lebih mudah didapatkan (Pawestri et al., 2018,113).

Material akustik adalah material yang dapat mengabsorbsi gelombang bunyi datang dengan kemampuan daya serap yang berbeda-beda. Koefisien absorbsi bunyi adalah tingkat penyerapan gelombang bunyi oleh material akustik. Koefisien absorbsi bunyi ditentukan oleh ukuran serat, lubang, porositas dan rongga. Koefisien absorbsi bunyi tinggi biasanya dimiliki oleh material yang tidak keras namun tegar. Syarat material akustik untuk mempunyai nilai impedansi akustik yang baik yaitu memiliki koefisien absorbsi bunyi yang tinggi (Samsudin et.al., 2016).

Semakin mahalnya harga barang termasuk peredam bunyi, maka masyarakat berupaya untuk mencari alternatif lain dengan memanfaatkan bahan yang berasal dari alam yang mudah didapatkan dengan cara memanfaatkan serat ijuk sebagai bahan peredam bunyi. Serat ijuk sebagai bahan pengisi dalam komposit, berfungsi sebagai penguat dari matriks. (Delly et.al., 2016).

Penelitian ini bertujuan untuk mengkaji seberapa besar tingkat bunyi yang dapat ditahan oleh komposit campuran ijuk dan gipsum.

\section{BAHAN DAN METODE}

Bahan yang digunakan sabuk ijuk, gipsum, semen putih. Sedangkan alat yang digunakan yaitu timbangan, saringan, sound level meter.

Bahan komposit terdiri dari: komposit 1 (10gram Ijuk, 35 gram Gipsum dan 50 gram Semen putih), komposit 2 (15 gram Ijuk, 30 gram Gipsum dan 50 gram Semen putih), Komposit 3 (20 gram Ijuk, 25 gram Gipsum dan 50 gram Semen putih), Komposit 4 (30 gram Ijuk, 15 gram Gipsum dan 50 gram Semen putih), dan Komposit 5 (35 gram Ijuk, 10 gram Gipsum dan 50 gram Semen putih).

Sabuk ijuk di potong yang sangat kecil, diayak dengan ayakan ukuran 10 mess, kemudian timbang gipsum dengan masing-masing ukuran yang telah ditetapkan. Lalu, timbang semen putih dengan masing-masing 50 gram sebagai perekat campuran ijuk dan gipsum. Komposit yang telah disiapkan dimasukkan dalam cetakan dengan ukuran panjang $10 \mathrm{~cm}$, lebar $10 \mathrm{~cm}$ dan tebal $1,5 \mathrm{~cm}$ kemudian dimasukkan dalam cetakan yang telah dibuat. Sampel komposit kemudian dipanaskan dengan cara dijemur sampai mengeras dan kering selanjutnya, sampel komposit diambil dari cetakan.

Bahan-bahan yang telah diperoleh tersebut digunakan sebagai penutup kotak (box), yang di dalamnya dimasukkan sumber bunyi, lalu dicatat 
intensitas bunyi dari masing-masing perlakuan.

Penelitian ini dilakukan pada waktu pagi hari pukul (08.00-08.10) sampai dengan selesai. Untuk menghindari terjadinya pantulan bunyi yang dapat menggangu bunyi yang diinginkan. Penelitian ini berlangsung mulai dari pukul (08.00-08.10) sampai dengan selesai.

Data pengamatan berupa intensitas bunyi dilakukan selama 10 menit dengan interval per 5 detik dengan 120 kali pengulangan. Data intensitas bunyi yang diperoleh dikumpulkan dalam bentuk tabulasi dan untuk mempermudah pembahasan ditampilkan dalam bentuk grafik.

Data penelitian diolah dengan mencari nilai eqivalen (Leq) untuk masing-masing waktu pengukuran. Leq dapat dihitung dengan:

Leq $=10 \log \left(\frac{1}{120} \sum_{1}^{120} 10^{\frac{L_{1}}{10}}\right) d B(A)$

Leq adalah tingkat kebisingan eqivalen atau tingkat kebisingan terukur dari masing-masing waktu pengukuran dinyatakan dengan satuan $\mathrm{dB}(\mathrm{A})$.

Data yang diperoleh lalu dianalisis sidik ragam uji $\mathrm{F}$, untuk melihat pengaruh bahan komposit dalam mengurangi intensitas bunyi dilakukan analisis sidik ragam Uji F. Nilai $F$ hitung $>\mathrm{F}$ Tabel 5\% artinya perlakuan bahan komposit berpengaruh nyata dalam menurunkan intensitas bunyi, untuk melihat perbedaan dari masing-masing perlakuan dalam menurunkan intensitas bunyi dilakukan Analisis Beda Nyata Terkecil (BNT).

\section{HASIL DAN PEMBAHASAN}

Penelitian ini dilakukan pada waktu pagi hari untuk menghindari terjadinya pantulan bunyi yang dapat menggangu bunyi yang diinginkan. Penelitian ini berlangsung mulai dari pukul (08.00-08.10) sampai dengan selesai. Hasil pengukuran intensitas bunyi yang diletakan dalam box (kotak) tanpa penutup di dapatkan data gambar 1 .

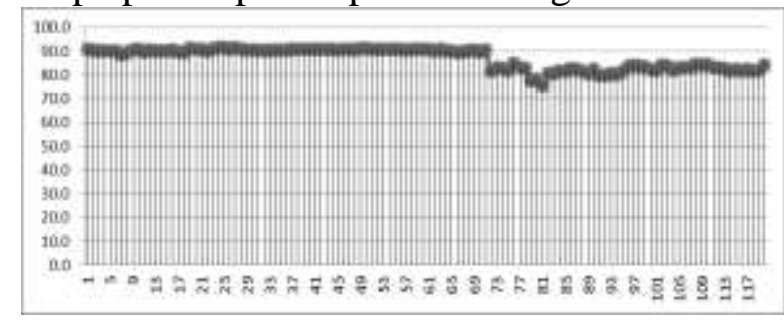

Gambar 1. Tingkat Intensitas Bunyi tanpa Komposit

Dari Gambar 1 dihitung nilai rata-rata intensitasnya dengan rata-rata dengan rumus berikut:

$$
\begin{aligned}
\text { Leq }= & 10 \log \left(\frac{1}{120} \sum_{1}^{120} 10^{\frac{L_{1}}{10}}\right) d B(A) \\
\text { Leq }= & 10 \times[\log 1-\log 120+\log \\
& (84127032236)] \mathrm{db}(\mathrm{A}) \\
\text { Leq }= & 10 \times[8.845754322] \\
\text { Leq }= & 88.45754322 \\
\text { Range }= & (75.5-91.2)
\end{aligned}
$$$$
\text { Average }=86.9
$$

Hasil perhitungan dengan rumus diatas terlihat bahwa intensitas bunyi rata-rata tanpa penutup nilainya yaitu $86,9(\mathrm{~dB})$.

\section{Intensitas Bunyi dengan menggunakan Gipsum}

Intesitas hasil dari pengukuran dengan menggunakan bahan gipsum didapatkan gambar 2

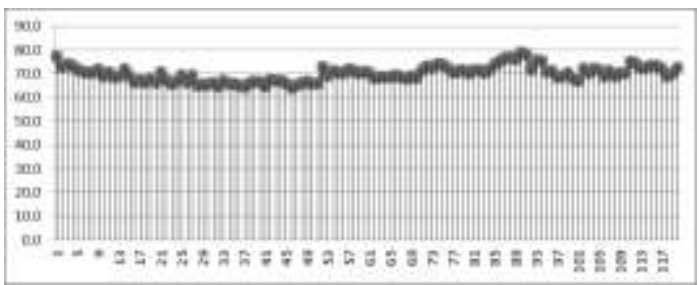

Gambar 2. Pengukuran Intensitas Bunyi dengan menggunakan Gipsum

Nilai rata-rata dari hasil pengamatan dapat dihitung nilai intensitas bunyi sebagai berikut:

$$
\begin{aligned}
\text { Leq }= & 10 \log \left(\frac{1}{120} \sum_{1}^{120} 10^{\frac{L_{1}}{10}}\right) d B(A) \\
\text { Leq }= & 10 \times[\log 1-\log 120+\log \\
& (1563170391)] \mathrm{db}(\mathrm{A})
\end{aligned}
$$


Leq $=10 \times[0-2.0791812469 .19400632$

Leq $=10 \times[7.114825074]$

Leq $=71.14825074$

Range $=(64.2-78.6)$

Average $=69.9$

Nilai intensitas bunyi sesaat untuk data waktu $(08.20-08.30)=69.9 \mathrm{~dB}(\mathrm{~A})$.

Hasil perhitungan dengan rumus diatas terlihat bahwa intensitas bunyi rata-rata dengan menggunakan gipsum nilainya adalah $69,9(\mathrm{~dB})$.

Dari Gambar 2 dapat dilihat pengaruh dari masing-masing bahan dimana intensitas bunyi dengan menggunakan gipsum dalam meredam suara dengan nilai $69.9(\mathrm{~dB})$. Bahan komposit I terbuat dari gipsum dengan diameter panjang $10 \mathrm{~cm}$ dan lebar $10 \mathrm{~cm}$. Penelitian ini dilakukan pada waktu pagi hari untuk menghindari terjadinya pantulan suara yang dapat menggangu bunyi yang diinginkan. Penelitian ini berlangsung mulai dari pukul (08.2008.30) sampai dengan selesai. Sehingga, pengamat dapat melakukan percobaan dan pengambilan data.

\section{Hasil Pengukuran Intensitas bunyi dengan menggunakan Komposit 1}

Nilai rata-rata dari hasil pengamatan dapat dihitung nilai intensitas bunyi sebagai berikut:

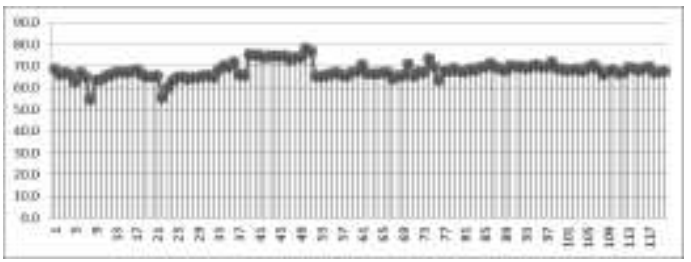

Gambar 3. Pengukuran Intensitas bunyi dengan menggunakan Komposit 1

$$
\begin{aligned}
\text { Leq }= & 10 \log \left(\frac{1}{120} \sum_{1}^{120} 10^{\frac{L_{1}}{10}}\right) d B(A) \\
\text { Leq }= & 10 \times[\log 1-\log 120+\log \\
& (1048819481)] \mathrm{db}(\mathrm{A}) \\
\text { Leq }= & 69.415195 \\
\text { Leq }= & 10 \times[0-2.0791812469 .020700746
\end{aligned}
$$

Leq $=10 \times[6.9415195]$

Leq $=69.415195$

Range $=(54.6-78.1)$

Average $=67.9$

Nilai intensitas suara sesaat untuk data waktu $(08.40-08.50)=67.9 \mathrm{~dB}(\mathrm{~A})$.

Hasil perhitungan dengan rumus diatas terlihat bahwa intensitas bunyi rata-rata dengan menggunakan komposit I nilainya $67,9(\mathrm{~dB})$.

Dari Gambar 3 dapat dilihat pengaruh dari masing-masing bahan dimana intensitas bunyi dengan menggunakan komposit I dalam meredam bunyi dengan nilai $67.9(\mathrm{~dB})$. Bahan komposit I terbuat dari 10 gram ijuk, 35 gram gipsum dan 50 gram semen putih. penelitian ini dilakukan pada waktu pagi hari untuk menghindari terjadinya pantulan bunyi yang dapat menggangu bunyi yang diinginkan. Penelitian ini berlangsung mulai dari pukul (08.40-08.50) sampai dengan selesai.

\section{Hasil Pengukuran Kebisingan dengan menggunakan Komposit II}

Nilai rata-rata dari hasil pengamatan dapat dihitung nilai intensitas bunyi sebagai berikut:

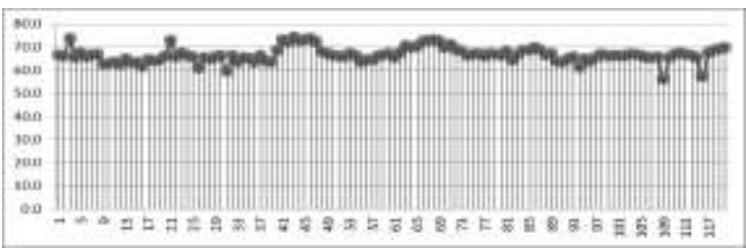

Gambar 4. Pengukuran Intensitas bunyi dengan menggunakan Komposit II

$$
\begin{aligned}
& \text { Leq }= 10 \log \left(\frac{1}{120} \sum_{1}^{120} 10^{\frac{L_{1}}{10}}\right) d B(A) \\
& \text { Leq }= 10 \times[\log 1-\log 120+\log \\
&(734409104)] \mathrm{db}(\mathrm{A}) \\
& \text { Leq }= 10 \times[0-2.0791812468 .865938052 \\
& \text { Leq }= 10 \times[6.786756806] \\
& \text { Leq }= 67.86756806 \\
& \text { Range }=(56.0-74.3) \\
& \text { Average }=66.6
\end{aligned}
$$


Nilai intensitas bunyi sesaat untuk data waktu $(09.00-09.10)=66.6 \mathrm{~dB}(\mathrm{~A})$

Dari Gambar 4 dapat dilihat pengaruh dari masing-masing bahan dimana intensitas bunyi dengan menggunakan komposit II dalam meredam bunyi dengan nilai $66.6(\mathrm{~dB})$. Bahan komposit I terbuat dari 15 gram ijuk, 30 gram gipsum, dan 50 gram semen putih. percobaan ini dilakukan pada waktu pagi hari untuk menghindari terjadinya pantulan bunyi yang dapat menggangu bunyi yang diinginkan. Penelitian ini berlangsung mulai dari pukul (09.00-09.10) sampai dengan selesai. Sehingga, pengamat dapat melakukan penelitian dan pengambilan data.

\section{Hasil Pengukuran Intensitas Bunyi dengan menggunakan Komposit III}

Nilai rata-rata dari hasil pengamatan dapat dihitung nilai intensitas bunyi sebagai berikut :

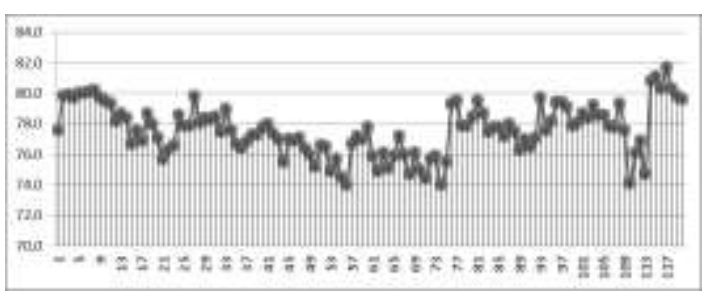

Gambar 5. Pengukuran Intensitas bunyi dengan menggunakan Komposit III

$$
\begin{aligned}
& \text { Leq }=10 \log \left(\frac{1}{120} \sum_{1}^{120} 10^{\frac{L_{1}}{10}}\right) d B(A) \\
& \text { Leq }=10 \times[\log 1-\log 120+\log \\
& \text { (7437633265)] db (A) } \\
& \text { Leq }=10 \times \quad\left[\begin{array}{ll}
0 & -2.079181246
\end{array}\right. \\
& \text { 9.87143476] } \\
& \text { Leq }=10 \times[7.792253514] \\
& \text { Leq }=77.92253514 \\
& \text { Range }=(74.0-81.7) \\
& \text { Average }=77.6
\end{aligned}
$$

Nilai intensitas bunyi sesaat untuk data waktu $(09.20-09.30)=77.6 \mathrm{~dB}(\mathrm{~A})$
Dari Gambar 5 dapat dilihat pengaruh dari masing-masing bahan dimana intensitas bunyi dengan menggunakan komposit III dalam meredam bunyi dengan nilai 77.6 (dB).Bahan komposit III terbuat dari 20 gram ijuk, 25 gram gipsum dan 50 gram semen putih. Penelitian ini dilakukan pada waktu pagi hari untuk menghindari terjadinya pantulan bunyi yang dapat menggangu bunyi yang diinginkan. Penelitian ini berlangsung mulai dari pukul (09.20-09.30) sampai dengan selesai. Sehingga, pengamat dapat melakukan percobaan dan pengambilan data.

\section{Hasil Pengukuran Intensitas Bunyi dengan menggunakan Komposit IV}

Nilai rata-rata dari hasil pengamatan dapat dihitung nilai intensitas bunyi sebagai berikut :

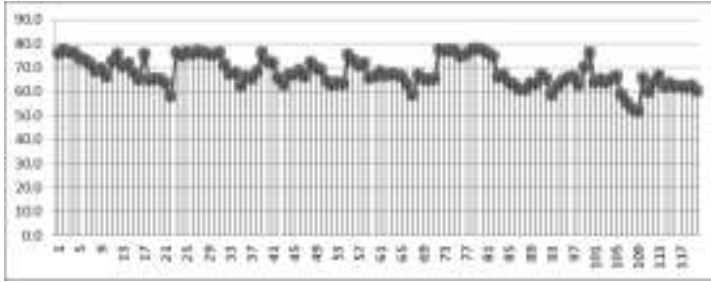

Gambar 6. Pengukuran Intensitas bunyi dengan menggunakan Komposit IV

$$
\begin{aligned}
& \text { Leq }=10 \log \left(\frac{1}{120} \sum_{1}^{120} 10^{\frac{L_{1}}{10}}\right) d B(A) \\
& \text { Leq }=10 \times[\log 1-\log 120+\log \\
& \text { (1699822880)] db (A) } \\
& \text { Leq }=10 \mathrm{x} \quad\left[\begin{array}{ll}
0 & -2.079181246
\end{array}\right. \\
& 9.230403671] \\
& \text { Leq }=10 \times[7.151222425] \\
& \text { Leq }=71.51222425 \\
& \text { Range }=(51.8-77.9) \\
& \text { Average }=68.0
\end{aligned}
$$

Nilai intensitas bunyi sesaat untuk data waktu $(09.40-09.50)=68.0 \mathrm{~dB}(\mathrm{~A})$

Dari Gambar 6 dapat dilihat pengaruh dari masing-masing bahan dimana intensitas bunyi dengan menggunakan komposit IV dalam 
meredam bunyi dengan nilai $68.0(\mathrm{~dB})$. Bahan komposit IV terbuat dari 30 gram ijuk, 15 gram gipsum dan 50 gram semen putih. Percobaan ini dilakukan pada waktu pagi hari untuk menghindari terjadinya pantulan bunyi yang dapat menggangu bunyi yang diinginkan. Penelitian ini berlangsung mulai dari pukul (08.40-08.50) sampai dengan selesai. Sehingga, pengamat dapat melakukan penelitian dan pengambilan data.

\section{Hasil Pengukuran Intensitas Bunyi dengan menggunakan Komposit $\mathbf{V}$}

Penelitian ini dilakukan pada waktu pagi hari untuk menghindari terjadinya pantulan bunyi yang dapat menggangu bunyi yang diinginkan. Penelitian ini berlangsung mulai dari pukul (10..0010.10) sampai dengan selesai. Hasil pengukuran intensitas bunyi yang diletakan dalam box (kotak) pada komposit $\mathrm{V}$ di dapatkan data gambar 7

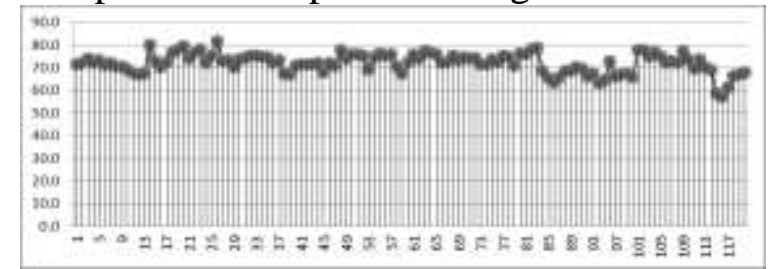

Gambar 7. Pengukuran Intensitas bunyi dengan menggunakan Komposit V

$$
\begin{aligned}
& \text { Leq }=10 \log \left(\frac{1}{120} \sum_{1}^{120} 10^{\frac{L_{1}}{10}}\right) d B(A) \\
& \text { Leq }=10 \times[\log 1-\log 120+\log \\
& \quad(2849798375)] \mathrm{db}(\mathrm{A}) \\
& \text { Leq }=10 \times[7.375632889] \\
& \text { Leq }=73.75632889 \\
& \text { Range }=(57.2-81.7) \\
& \text { Average }=72.0
\end{aligned}
$$

Nilai intensitas bunyi sesaat untuk data waktu $(10.00-10.10)=72.0 \mathrm{~dB}(\mathrm{~A})$

Dari Gambar 7 dapat dilihat pengaruh dari masing-masing bahan dimana intensitas bunyi dengan menggunakan komposit $\mathrm{V}$ dalam meredam suara dengan nilai $72.0 \mathrm{~dB}(\mathrm{~A})$.
Bahan komposit $\mathrm{V}$ terbuat dari 35 gram ijuk, 10 gram gipsum dan 50 gram semen putih. Percobaan ini dilakukan pada waktu pagi hari untuk menghindari terjadinya pantulan suara yang dapat menggangu bunyi yang diinginkan. Penelitian ini berlangsung mulai dari pukul (10.00-10.10) sampai dengan selesai. Sehingga, pengamat dapat melakukan percobaan dan pengambilan data.

Berdasarkan hasil semakin tinggi frekuensi intensitas bunyi yang dihasilkan untuk penelitian komposit $\mathrm{V}$ dengan menggunakan alat sound level meter (SLM) dilakukan selama 10 menit bernilai $72.0 \mathrm{~dB}(\mathrm{~A})$. hal ini disebabkan karena frekuensi intensitas bunyi semakin besar disebabkan juga karena tidak ada kompositsehingga energy gelombang bunyi semakin besar dihabiskan oleh peristiwa resonansi dalam rongga sehingga nilai koefisien absorbsi nya rendah. Berdasarkan data grafik diatas dapat dibuat dalam satu grafik antara berbagai jenis bahan (1) tanpa komposit/tanpa penutup, (2) dengan gipsum, (3) komposit 1,, (4). Komposit II, (5) Komposit III, (6) Komposit IV, (7) Komposit V sehingga diperoleh gambar 8.

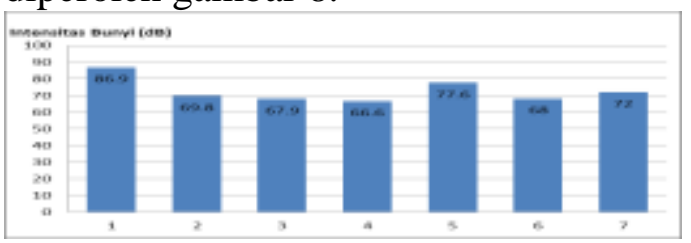

Gambar 8. Hasil dari Penelitian

Intensitas Bunyi dengan Interval per 5 detik

Setelah dilakukan pengujian, kemudian dihitung nilai koefisien absorbsi masing-masing sampel. Hal ini menunjukkan bahwa nilai tingkat tekanan bunyi yang diberikan pada tiap-tiap sampel peredam akustik sebagian besar akan diserap dan sebagian lainnya akan dipantulkan kembali.

Pada sampel yang ketebalannya tinggi, energi bunyi akan susah yang 
menerobos material tersebut karena rongganya kecil, sedangkan impedansinya besar, dan kecepatan partikel bunyi kecil sehingga bunyi lebih banyak dipantulkan dari pada diserap. Material yang memiliki tingkat redam yang paling baik yaitu memiliki koefisien serap bunyi paling besar dibandingkan dengan yang lain yaitu pada komposit III (Fatkhurrohman dan supriyadi, 2013, 141).

Gelombang bunyi pada frekuensi ini lebih banyak siserap melalui pori yang ada pada sampel dari pada dipantulkan. Pori-pori pada sampel ditentukan oleh perbandingan massa antara serat dan semen putih. Banyaknya pori pada sampel akan memudahkan gelombang bunyi untuk masuk. Sehingga nilai koefisien absorbsi yang dihasilkan akan lebih baik dalam menyerap suara.

Hasil analisis sidik ragam (uji F) dengan cara menginputkan data dari hasil pengamatan ke program SPSS, didapatkan data tabel 1 dan 2.

Tabel 1. Uji F Intensitas Suara

\begin{tabular}{ll|l|l|l|l}
\hline & $\begin{array}{l}\text { Sum of } \\
\text { Squares }\end{array}$ & Df & $\begin{array}{l}\text { Mean } \\
\text { Square }\end{array}$ & F & Sig. \\
\hline $\begin{array}{l}\text { Between } \\
\text { Groups }\end{array}$ & 37974,781 & 6 & 6329,130 & 407,253 &, 000 \\
\hline $\begin{array}{l}\text { Within } \\
\text { Groups }\end{array}$ & 12945,682 & 833 & 15,541 & & \\
\hline Total & 50920,463 & 839 & & & \\
\hline
\end{tabular}

Dari Tabel 1 terlihat bahwa nilai uji $F$ 407,253 dengan tingkat signifikan (sig.) $0,000<0,05(5 \%)$, artinya setiap perlakuan dari berbagai bahan yang digunakan dalam usaha menguranggi intensitas bunya menunjukan perbedaan yang nyata, untuk melihat perbedaan antar perlakuan dari berbagai bahan tersebut dilakukan analisis Beda Nyata Terkecil (BNT). Hasil analisis BNT didapatkan tabel 2 .

Tabel 2. Analisis BNT Antar Perlakuan

\begin{tabular}{|c|c|c|c|c|}
\hline $\begin{array}{l}\text { (I) } \\
\text { Jenis }\end{array}$ & $\begin{array}{l}(\mathrm{J}) \\
\text { Jenis }\end{array}$ & $\begin{array}{l}\begin{array}{l}\text { Mean } \\
\text { Difference } \\
(\mathrm{I}-\mathrm{J})\end{array} \\
\end{array}$ & $\begin{array}{l}\text { Std. } \\
\text { Error }\end{array}$ & Sig. \\
\hline \multirow[t]{3}{*}{1} & 2 & 17,02667 & ,50894 & ,000 \\
\hline & 3 & $19,01167^{*}$ &, 50894 & ,000 \\
\hline & 4 & 20,25917 &, 50894 & ,000 \\
\hline
\end{tabular}

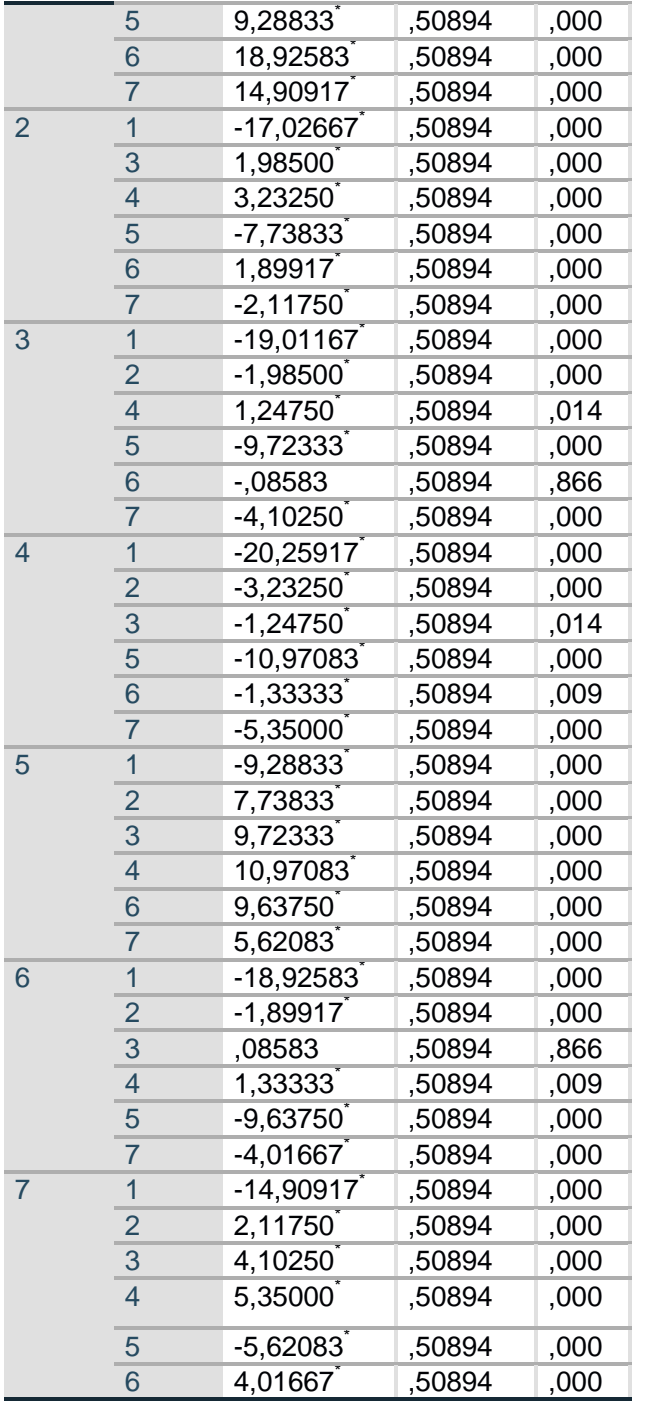

*. The mean difference is significant at the 0.05 level. Keterangan 1= Tanpa penutup, 2=Gipsum, 3=Komposit I, 4=Komposit II, 5=Komposit III, 6=Komposit IV dan 7=Komposit V

Dari Tabel 2 terlihat bahwa secara umum antar perlakuan menunjukan perbedaan yang nyata. Hal ini ditunjukan dengan tanda $(*)$, hanya perlakuan 3 terhadap perlakuan 6 , ataupun sebaliknya perlakuan 6 terhadap perlakuan 3 yang menunjukan perbedaan yang tidak nyata.

Berdasarkan hasil penelitian diatas bahwa semakin tebal sampel maka koefisien serap bunyi akan semakin kecil. Hal ini mungkin terjadi karena material yang ketebalannya rendah cenderung lebih besar dibandingkan dengan material yang ketebalannya tinggi, sehingga bunyi mudah diserapoleh sampel (Hayat et.al., 2013,

49). 
Berdasarkan hasil penelitian diatas bahwa semakin tebal sampel maka koefisien serap bunyi akan semakin kecil. Hal ini mungkin terjadi karena material yang ketebalannya rendah cenderung lebih besar dibandingkan dengan material yang ketebalannya tinggi, sehingga bunyi mudah diserapoleh sampel (Hayat et.al., 2013, 49).

\section{KESIMPULAN}

Intensitas bunyi tanpa bahan penutup (intensitas awal) sebesar 86,9 dB., sedangkan intensitas bunyi yang dapat ditahan dari bahan gipsum, komposit 1 , 2, 3, 4 dan masing-masing bernilai 69,8 $\mathrm{dB} ; 67,9 \mathrm{~dB} ; 66,6 \mathrm{~dB} ; 77,6 \mathrm{~dB} ; 68 \mathrm{~dB}$; $72 \mathrm{~dB}$

\section{DAFTAR PUSTAKA}

Addina, S., \& Keman, S. (2015). Hubungan Tingkat Kebisingan Lalu Lintas dengan Peningkatan Tekanan Darah dan Gangguan Pendengaran Tukang Becak dI Sekitar Terminal Purabaya Surabaya. Jurnal Kesehatan Lingkungan. 8(1), 69-80

Anggraini., Bima., dan Dewi. 2013. Penentuan Tingkat Kebisingan lalu lintas di Jalan Tuanku Tambusai Pekanbaru. Pekanbaru: Fakultas Matematika dan Ilmu Pengetahuan Alam Universitas Riau.

Amaliyah, D. M., \& Hamdi, S. 2015. Sifat Fisik Mekanik Papan Gypshum Berbahan Pengisi Alternatif Limbah Serutan Rotan. Jurnal Riset Industri Hasil Hutan. 7(1), 21-30.

Darmawi. M., dan A. M. (2013).

Pengaruh Penambahan Serat Ijuk Terhadap Sifat Fisis dan Mekanik Papan Semen-Gipsum. Jurnal Fisika Unand, 2 (1),
Delly, J., Aminur dan Leo, L., 2016.

Analisa Mampu Redam Komposit Polyester Diperkuat Serat Batang Pisang. ENTHALPY- Jurnal Ilmiah Mahasiswa Teknik Mesin, 1(1), pp.7-12

Departemen Tenaga Kerja RI.2011. Nilai Ambang Batas Fisika di Tempat Kerja. Jakarta: DEPNAKER RI.2011

Dewanty, R. A., \& Sudarmaji, S. 2016. Impact Analysis of Noise Intensity with Hearing Loss on Laundry Worker. Jurnal Kesehatan Lingkungan. 8(2), 229237.

Fakhurrohman, M. A., dan Supriyadi. 2013. Tingkat Redam Bunyi Suatu Bahan (Triplek,Gypshum dan Styropoam). Jurusan Pendidikan IPA Konsentrasi Fisika, PPs UNNES Kampus Bendan Ngisor Semarang. 3 (2).

Hamdi, S. 2012. Pengawetan Rotan Kurang Dikenal Sebagai Bahan Baku Mebel Menggunakan Rendaman Dingin. Jurnal Riset Industri Industri Hasil Hutan Vol.4 No.2, Hal 11-15.

Handoko, S. 2010. Kebisingan dan Pengaruhnya Pada Lingkungan Hidup. Universitas Mercu Buana. Jakarta.

Hanafi. 2010. Penyerapan Bunyi oleh Dinding dan Lapisan. UNS Repoistory.

http://Hanafi.blog.uns.ac.id/2010/09/24/p enyerapan-bunyi-oleh-dindingdan lapisan/14 juni 2021

Hayat, W., Syakbaniah,dan Darvina, Y. (2013). Pengaruh Kerapatan terhadap Koefisien Absorbsi Bunyi Papan Partikel Serat Daun 
Nanas, Jurnal Pillar of physics, 1, 44-51.

Idris, I., Mangalla, L. K., \& Sudia, B. 2018. Pengaruh Variasi Komposisi Komposit Berbahan Gypshum, Serat Ijuk Pohon Aren dan Resin Polyester Terhadap Kemampuan Meredam Suara. Jurnal Ilmiah Mahasiswa Teknik Mesin. 3(2), 2502-8944.

Ikhsan, K., Elvaswer., \& Harmadi. 2016. Karakteristik Koefisien Absorbsi Bunyi dan Impedansi Akustik dari Material Berongga Plafon PVC Menggunakan Metode Tabung Impedansi. Jurnal Ilmu Fisika. 8(2) ISSN 1979-4657.

Kementrian Lingkungan Hidup Republik Indonesia. 1996. Keputusan Menteri Negara Lingkungan Hidup Nomor 48 Tahun 1996 Tentang Baku Mutu Tingkat Kebisingan

Lewis, H. dan Douglas, H., 1993. Industrial Noise Control Fundamentals and Application, Reyised, New York.

Mahmuda, E., S. Savetlana, \& S. Sugiyanto. 2013. Pengaruh Panjang Serat Terhadap Kekuatan Tarik Komposit Berpenguat Serat Ijuk dengan Matrik Epoxy. Jurnal FEMA, 1(3): 79-84.

Nilson, P.O.L., 1990. Noise Induced Hearing Loss, Proceedings of the 5Th International Congress on Noise as a Public Health Problem. Volume 4, Swedish Council for Building Research: Stockholm

Pawestri, A. K. R., Hasanah, W., dan Murphy, A. (2018). Studi Karakteristik Komposit Sabut Kelapa dan Serat Daun Nanas sebagai Peredam Bunyi, Jurnal
Teknologi Bahan Alam, 2 (2), 112-117.

Pratama, R., M. Dirhamsyah, dan N. Nurhaida. 2019. Sifat Fisik dan Mekanik Papan Gypshum dari Limbah Kayu Akasia (Acacia Mangium Wild) Berdasarkan Kadar Gipshum dan Ukuran Serbuk Kayu. Jurnal Hutan Lestari. 7(1): 305-315.

Puspitarini, Y., A. S, F. M., dan Yulianto, A. 2014. Koefisien Serap Bunyi Ampas Tebu Sebagai Bahan Peredam Suara. Jurnal Fisika. 4(2) 96-100.

Rahmawati, E. D. A. (2015). Dampak Intensitas Kebisingan Terhadap Gangguan Pendengaran (Auditory Effect) Pada Pekerja di Pabrik IPT. Petrokimia Gresik. Skripsi. Jember: Fakultas Kesehatan Masyarakat Universitas Jember.

Nurkholis., Junaidi dan A. Surtono. (2014). Rancang Bangun Sistem Akuisisi Data Resonansi gelombang Bunyi Menggunakan Transduser Ultrasonik Berbasis Mikrokontroler ATmega8535. Jurnal Teori dan Aplikasi Fisika. Vol. 02 No 02.

Rujigrok GJJ., 1993, Elemen of Aviation Acoustics. Delft University Press. Young HD, Freedman OA. Fisika Universitas, Jilid

Sriwita, D. dan Astuti. 2014. Pembuatan dan Karakteristik Sifat Mekanik Bahan Komposit Serat Daun Nanas- Polyester Ditinjau dari Fraksi Massa dan Orientasi Serat. Jurnal Fisika Unand. 3(1):30-36

S. Y., \& Elvaswer, E. (2018). Karakterisasi Koefisien Absorbsi Bunyi dan Impedansi Akustik 
Pembuatan Komposit sebagai...Jupiter... Vol 2 No 2...Februari 2021...66-75

Indah Safitri, Parmin Lumbantoruan, Andi Arif Setiawan

dalam Limbah Serat Kayu

Meranti Merah (SHOREA

PINANGA) dengan

menggunakan Metode Tabung.

Jurnal Ilmu Fisika (JIF), 10 (1).

Samsudin, E. M., Ismail, L. H., \& Kadir, A. A. (2016). A Review On Physical, Factors Influencing Absorption Perfomance Offibrous Sound Absorption Material From Natural Fibers. Journal of Engineering and Applied Sciences, 11 (6).

Tarwaka, (2010). Ergonomi Industri. Surakarta: Harapan Press. Infokes, Vol. 5

Hilda. T., \& A. Mahyudin. (2012). Analisis Sifat Fisis dan Mekanik Papan Komposit Gipsum Serat Ijuk Dengan Penambahan Boraks (Dinatrium

Tetraborat Decahydrate). Jurnal Fisika Unand, 1 (1).

Trisnayanti Y, Eko S, M. F., \& I. K. (2014). Mutu Papan Gipsum dari Serat Daun Nanas dan Serbuk Gergaji Kayu Meranti dan Implementasinya Pada Pembelajaran Fisika. Jurnal Pendipa, 1 (1) : 33-41

Wahyudi, S.2016. Karakteristik Komposit Partikel Ijuk Mesh 100 Menggunakan Matrik Karet Dengan Komposisi 0phr, 10phr, $20 \mathrm{Phr}$ Terhadap Radiasi Sinar Gamma. Skripsi, Program Studi Strata Satu Pada Jurusan Teknik Mesin Fakultas Teknik Universitas Muhammadiyah Surakarta (Tidak dipublikasikan).

Yasid, A., Yushardi dan R.D. Handayani. (2016). Pengaruh Frekuensi Gelombang Bunyi terhadap Perilaku Lalat Rumah (Musca domestica). Jurnal Pembelajaran
Fisika, Vol. 5 No. 2, September 2016, hal $190-196$. 